\title{
OPTIKAI ELVEN TÖRTÉNŐ ALAKVÁLTOZÁS MÉRÉSE AZ AKADÉMIAI ÉS AZ IPARI GYAKORLATBAN
}

\author{
Kovács Péter Zoltán \\ egyetemi docens, Miskolci Egyetem, Anyagszerkezettani és Anyagtechnológiai Intézet \\ 3515 Miskolc, Miskolc-Egyetemváros, e-mail: metkpz@uni-miskolc.hu
}

\begin{abstract}
Absztrakt:
A jármüipar rohamos fejlödésével ugrásszerüen megnött az igény az új, illetve különbözö módositásokkal továbbfejlesztett alapanyagokra. Ezen alapanyagokkal szemben számos elvárást támasztott az ipar, melyek közül az egyik legjelentösebb a felhasznált anyagok tömegének csökkentése. Ez mind gazdasági, mind pedig környezetvédelmi szempontból kiemelt fontossággal bir, mert az össztömeg csökkenésével a károsanyag kibocsátás is mérsékelhetö. Mindemellett fontos, hogy az anyag eredeti szilárdsági tulajdonságait megtartsák, lehetöség szerint javitsanak rajta. A cikkben meghatározásra kerül egy nagyszilárdságú anyag (DP 600) alakitási határdiagramj, valamint annak felhasználása egy végeselemes (AutoForm R7) szoftverkörnyezetben. A tanulmány keretében bemutatásra kerül, hogy a végeselemes szoftverben kapott eredmények hogyan finomithatók a modellezéshez felhasznált anyag anyagkártyájának meghatározása segitségével.
\end{abstract}

Kulcsszavak: alakitási határdiagramok (FLD), nagyszilárdságú acél, AutoForm

\begin{abstract}
:
With the rapid development of the automotive industry, the demand for new and improved materials has changed dramatically. The industry has set many expectations for these raw materials, one of the most significant of which is the reduction of the weight of the materials used. This is of great economic and environmental importance, as by reducing the total weight, emissions can be reduced. However, it is important that the original strength properties of the material are maintained and, where possible, improved. This article defines a high strength material (DP 600) forming limit diagram and its use in a finite element (AutoForm R7) software environment. The study presents how finite element software results can be refined by defining the material map of the material used for modeling.
\end{abstract}

Keywords: forming limit diagrams (FLD), high strength steel, AutoForm

\section{Bevezetés}

A korszerủ anyagokból készült alkatrészek alakítása során a hagyományos tervezés esetében számos szerszámkialakítást és próbát követően jutnak a mérnökök sikeres végeredményre. Ez a folyamat nagy költségvonzattal rendelkezik és mindemellett rendkívül időigényes. Erre a problémára szolgál 
megoldással a végeselemes módszereket alkalmazó szoftver rendszerek alkalmazása. A szerszámpróbákat számítógépes környezetben lehet szimulálni és minden szimulációt követően változtatni azon az eredmények függvényében.

Az alakíthatóság meghatározására lemezanyagok esetében az alakíthatósági határdiagramokat (FLD - Forming Limit Diagram) és az alakítási határgörbéket (FLC - Forming Limit Curve) alkalmazzák. Az említett szoftvereknek is fontos bemeneti paramétere az FLD diagram, hiszen ez szolgál adattal az alakítási müvelet sikerességéröl és az esetleges veszélyzónákról. Ezáltal a károsodásnak fokozottan kitett tartományok a tényleges gyártás előtt detektálhatók és ennek függvényében módosítható a szimuláció. Az FLD diagramot egy adott anyagminőség esetében az anyagmodell tartalmazza, amely szükséges bemeneti paraméter a szimuláció futtatásához.

\section{Alakíthatósági vizsgálatok}

Az alakíthatóság vizsgálata nagy jelentőséggel bír napjainkban, hiszen a tömegcsökkentés szempontjából a fontos szilárdsági követelmények az alakíthatóságot sok esetben lerontják. Ez annak a következménye, hogy az alakítás során történő szilárdság növeléssel egyidőben az alakváltozási tulajdonságok fokozatosan csökkennek a fémek képlékeny alakítása során. Az ipar fejlődése által megkövetelt szilárdsági jellemzők biztosítása mellett fontos, hogy az anyag alakíthatósága ne csökkenjen le túlságosan. Emiatt az alakváltozó képesség meghatározása fontos szerepet tölt be a fejlesztések területén. A lemezanyagok alakíthatóságának jellemzésére és számszerü értékkel történő meghatározására több eljárás is kialakult az évek során, többek között az alakíthatósági határdiagramok, az FLD-k.

Az alakíthatóság vizsgálatára több eljárás is ismert, melyeket hosszú ideje alkalmaznak. Ezek az eljárások a technológiai vizsgálatok, melyek ma már klasszikusnak is tekinthetők, hiszen évtizedek óta ismert és alkalmazott technológián alapszanak [1].

Az alakíthatósági határdiagramok (FLD - Forming Limit Diagram) a károsodási határértékeket ábrázolják a legnagyobb és a legkisebb főalakváltozások ( $\varepsilon 1$ és $\varepsilon 2)$ koordináta rendszerében. ( $\mathrm{Az}$ angol szakirodalom major és minor strain megnevezést használja az $\varepsilon 1$ és $\varepsilon 2$ értékekre.) $\mathrm{Az}$ alakváltozás során, a határérték elérése után következik be a károsodás, azaz a tönkremenetel. Ezt a határt jelölik az alakítási határgörbék, az FLC-k (Forming Limit Curves). Az FLD-t a legszélesebb körben a vékonylemezek alakíthatóságának jellemzésére használják. A diagram segítségével kontrolálhatók a lemezalakítási folyamatok úgy, hogy ne történjen szakadás az anyagban. Minden lemez anyagnak megvan a saját alakítási határgörbéje, mellyel meghatározhatók az alakíthatósági korlátai [2].

\subsection{Végeselemes módszerek a lemezalakításban}

A számítástechnika rohamos fejlődésének köszönhetően bonyolult modellezések, gyors számítások és a kapott eredmények azonnali értékelése lehetséges. Az ipar számára számos végeselemes módszert (röviden VEM) alkalmazó szoftver érhető el a piacon. Alkalmazásukhoz nem szükséges a teljes matematikai háttér ismerete ezzel megkönnyítve a szoftvert használó mérnökök dolgát. Ezen szoftverek jelentősége kiemelten fontos az autóipartól egészen az ürkutatás területéig, hiszen a gyors tervezés és a lehető leggazdaságosabb megoldás tölti be a legnagyobb szerepet. Manapság a 
legkorszerübb szoftverek állnak a mérnökök rendelkezésére melyekkel virtuális környezetben szimulálhatók a különféle lemezalakítási müveletek. [2] [4].

A legtöbb esetben lemezalakításkor jellemzően mélyhúzási, hajlítási vagy sajtolási technológiát kell megvalósítani, ebből kifolyólag nem csak a technológiatervezésben, hanem a különbözö technológiai próbák szimulálásban is szoftveres segítséget nyújtanak a végeselemes megoldások. Az alakíthatóság jellemzésére szolgáló FLD kísérleti módszerekkel történő meghatározásához alkalmazott eljárások, mint az Erichsen- és csészehúzó-vizsgálat, vagy a Nakazima-vizsgálat is modellezhető, ezen szoftverekben.

A VEM szoftverek előnye, hogy a szimuláció lefutását követően az alakítás bármely időpillanatára gyorsan meghatározható a próbatest bármely pontjára az alakítási határdiagram. Ezzel a kiértékelés idejét rendkívül lerövidíti. További előny, hogy idő és költségtakarékos megoldás, hiszen nem szükséges a próbatestek legyártása, a szimuláció elökészítése és elvégzése [4].

\subsection{AutoForm}

Az AutoForm manapság egyike a legkorszerübb véges elemes szoftvereknek, amely a lemezalakítás területén alkalmazható, szerszámtervezés, technológia tervezés és különféle kiértékelések elvégzésére. A képlékeny lemezalakítás területén a szoftver alkalmazásával csökkenthető mind tervezési idő, mind a szerszámpróbák száma, ezzel egy időben magasabb minőségü szerszám és munkadarab konstrukció hozható létre az optimális gyártás érdekében. Az AutoForm szoftverrendszer a különféle lemezalakítási folyamatok minden területén segítséget nyújt a mérnökök számára. Az egyszemélyes magánfelhasználástól egész a nagy vállaltokig mindenki számára biztos megoldást nyújt a számos integrált modult alkalmazó szoftver. Az AutoForm számos területen nyújt segítségét a mérnöki munkában, a teljesség igénye nélkül ezek a következők: alkatrésztervezés, folyamattervezés, szerszámtervezés, technológiatervezés [5].

Az AutoForm szoftver rendszerébe különféle geometriák, például munkadarabszerszámgeometriák, görbék, pontok és koordinátarendszerek importálhatók, melyek módosítására a szoftveren belül is van lehetőség, amennyiben az adott feladat ezt megköveteli. Ezzel megkönnyítve a tervezést és nagyfokú rugalmasságot biztosít a mérnökök számára. Az AutoForm szoftverben történő tervezést, az egymást követő fázisok sorban történő elvégzésével lehet megvalósítani. A szoftver úgy van kialakítva, hogy a tervezés során egymást követö lépések átláthatók és könnyen hozzáférhetők legyenek a tervezési folyamat bármely szakaszában.

A kiértékeléskor a kapott értékek alakítási határdiagrammon is megjelennek, melynek nagy szerepe van a lemezalaktás sikerességének a meghatározásában. Az 1. ábra az „Evaluation” szakaszban megjelenő alakítási határdiagrammot és annak részeit ábrázolja.

$\mathrm{Az}$ 1. jelü terület a biztonságos alakítás tartományát jelölei, ahol az alakított munkadarab az alakváltozás szempontjából megfelelö. A 2. terület az FLC görbe felett (fekete görbe) a szakadási, törési tartomány, ahol az anyag tönkremenetele történik. A 3. jelzésű részen a szakadás szempontjából kritikus tartomány, a 4. jelü területen pedig a túlzott elvékonyodás tartománya található. Az 5. tartományon belülre eső alakváltozott térfogatok nyomó igénybevételnek vannak kitéve. Ezen tartomány alatt található a 6 . terület, ahol az anyag ráncosodása következik be. A 7 . jellel ellátott terület a diagramon alig észrevehető, mert ez egy nagyon kicsi tartomány, ami az elégtelen 
alakváltozáshoz tartozik. A felsorolt területek segítségével nem csak a szakadásnak kitett tartományok, hanem más károsodási jelenségek is nyomon követhetők a teljes munkadarab felületén [3].

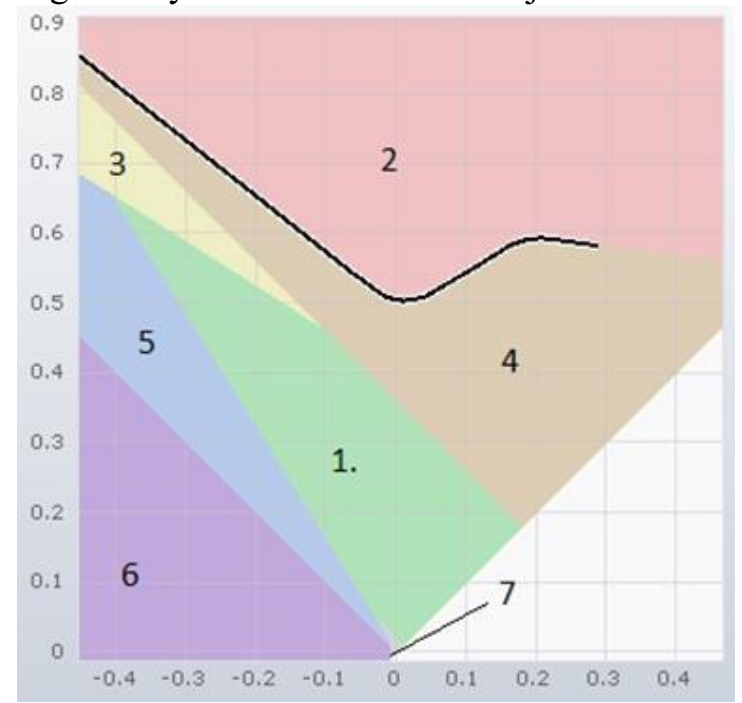

1. ábra. Az AutoForm szoftverben alkalmazott FLD és jellegzetes területei

\subsection{Nakazima vizsgálat elvégzése DP600 anyag FLD diagramjának meghatározásához}

A vizsgálatot és annak kiértékelését a Miskolci Egyetem Anyagszerkezettani és Anyagtechnológiai Intézetében megtalálható számítógép vezérlésű elektro-hidraulikus lemezvizsgáló berendezésén végeztem. A géphez tartozik egy automatizált alakváltozás mérő rendszer is, mely négy kamerából áll és az alakítás során rögzíti a teljes folyamatot, majd ezt követően automatikusan kiértékeli a kapott eredményeket.

A vizsgálatnál alkalmazott lemezanyag $1 \mathrm{~mm}$ vastag, DP600 hidegen hengerelt, nagyszilárdságú acél. Ezek az acélok szövetszerkezete jellemzően lágy ferritbe ágyazott martenzitből áll, de a martenzit mellett gyakran megjelenik bainit szövetelem is. A gépjármüvek súlyának csökkentését úgy valósítják meg, hogy növelt szilárdságuknak köszönhetően vékonyabb lemezvastagságok alkalmazhatók az egyes karosszériaelemek kialakítása során. Az alapmátrix jó alakíthatóságának köszönhetően kifejezetten jók képlékeny alakításra.

\subsection{Nakazima-vizsgálat laboratóriumban}

A DP600-as anyag alakítási határgörbéjének a meghatározásához a Miskolci Egyetem Anyagszerkezettani és Anyagtechnológiai Intézetének laboratóriumában megtalálható elektrohidraulikus lemezvizsgáló gépet használtam, mely számítógépes vezérléssel van ellátva. A berendezéshez tartozik egy optikai alakváltozást mérö rendszer is. A lemezvizsgáló gépet és a hozzá tartozó kamera rendszert ábrázolja a 2. ábra. 


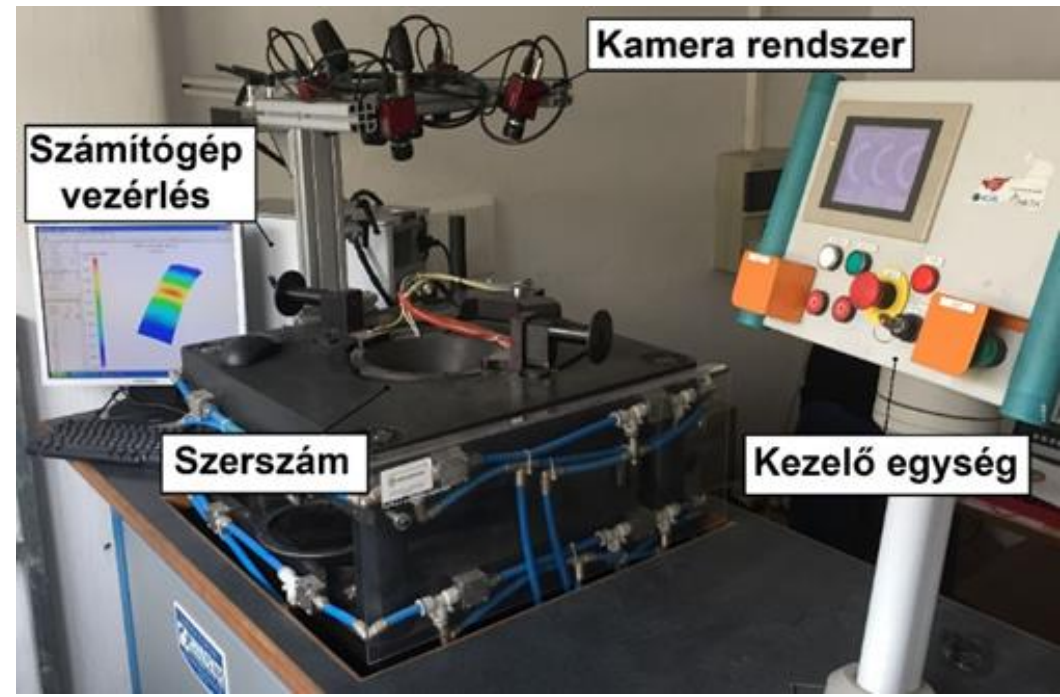

2. ábra. Az intézeti lemezvizsgáló berendezés

\subsection{AutoGrid szoftverben FLD meghatározása}

Vizsgálat végrehajtása és a szükséges rácshálók definiálása után minden információ rendelkezésre áll, hogy a szoftveren belül létrehozzam az FLD diagramot. Ahogy a képek kiértékelésénél a rácspontok meghatározása is automatikus módon ment, úgy az alakítási határdiagram létrehozása is nagyrészt automatikus. A rögzített képek közül, azt a képszámot kell megkeresni, ahol a repedés megjelent. Ezt követően ahhoz a képhez tartozó adatokat egy alakítási határdiagramon ábrázolva megkaptam az adott hídszélességü próbatest alakítási útvonalát pontfelhők formájában. Az öt különböző próbatest (rendre 20, 40, 80, 125 és $200 \mathrm{~mm}$ hídszélesség) esetében létrehozott alakítási útvonalat szemléltető pontfelhőket a 3. ábra összegzi.

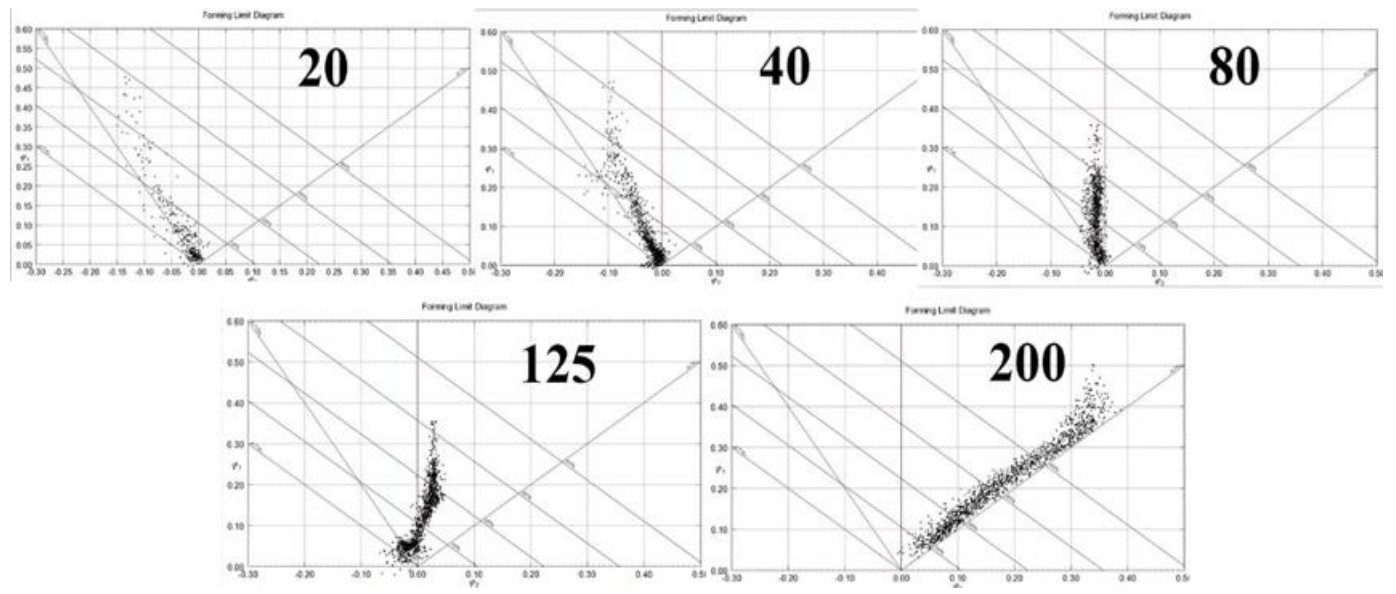

3. ábra. A különbözö hídszélességü próbatestek alakitási útvonalai 
A különböző hídszélességủ próbatesteknek köszönhetően az alakítási határdiagram jobb és bal oldalát is egyaránt le lehet fedni. Minden hídszélességhez más-más alakítási útvonal tartozik, melyeket egy diagramon ábrázolva láhatóvá válik a teljes FLD. Az egyes alakítási útvonalaknál a töréshez tartozó pontokat összekötve egy görbe rajzolható a diagramra, ami az alakítási határgörbét (FLC) jelöli. Ez az a kritikus érték, ahol a próbatestek az alakváltozás hatására elrepednek/eltörnek. Az FLD-t és a diagramon feltüntetett FLC-t a 4. ábra mutatja.

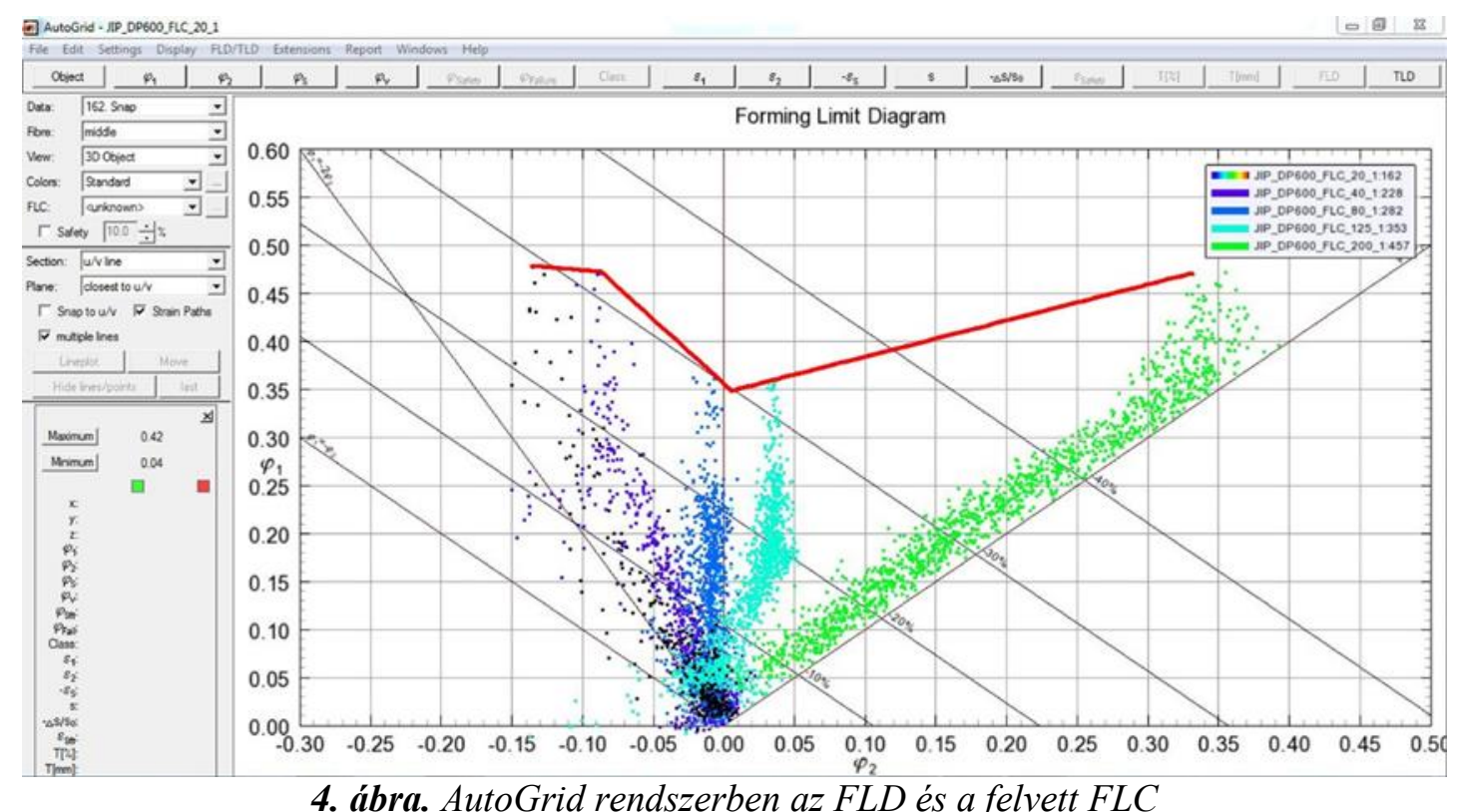

\section{Nakazima vizsgálat modellezése AutoForm R7 szoftverben}

A teljes FLD felvétele laboratóriumi vizsgálatokkal az előkészítéstől a végeredményig, akár 2-3 napot is igénybe vehet, viszont a képlékeny alakítás szoftveres szimulációjánál elengedhetetlen bemeneti paraméterként szerepel. Az AutoForm szoftverben számos, elöre definiált anyag közül lehet választani. Az adatbázisban megtalálható összes anyagra jellemző tulajdonságok és görbék (köztük az FLD-k) laboratóriumi körülmények között lettek felvéve. A szoftver ezeket a paramétereket használja bementi értékként, amikor egy anyagot választunk. Korlátjuk, hogy csak adott összetételü anyag egy bizonyos lemezvastagságára tartalmaznak pontos adatot. A lemezvastagság változtatásakor a szoftver számításokkal tolja el a görbét a megfelelő irányba.

A vizsgálatnál alkalmazott DP600 anyag azon adatait vittem be a szoftverbe, melyek egy anyagminőség meghatározásához szükséges. Ezek a következők:

a) folyásgörbe;

b) folyási határfelület;

c) alakítási határdiagram. 
A felsorolt görbékhez szükséges adatokat meghatároztam. Szakítóvizsgálattal az 5. ábrán szereplö a) és b) görbék, Nakazima vizsgálattal pedig a c) diagram meghatározásához szükséges adatokat hoztam létre. Az FLD bevitelekor a laboratóriumi vizsgálatból származó alakítási diagram, közelítő (kiegyenesített) változatát alkalmaztam. Az adatok bevitelét követően az „export” funkció segítségével elmentettem az általam létrehozott anyagot, hogy a későbbiekben ne legyen szükség az adatok újból a bevitelére, hanem csak egyszerúen betöltöm az adott anyagot ugyan úgy, mint egy előre meghatározott anyagot az AutoForm adatbázisából. Az általam bevitt DP600 anyag három fő paramétere látható az 5. ábrán.

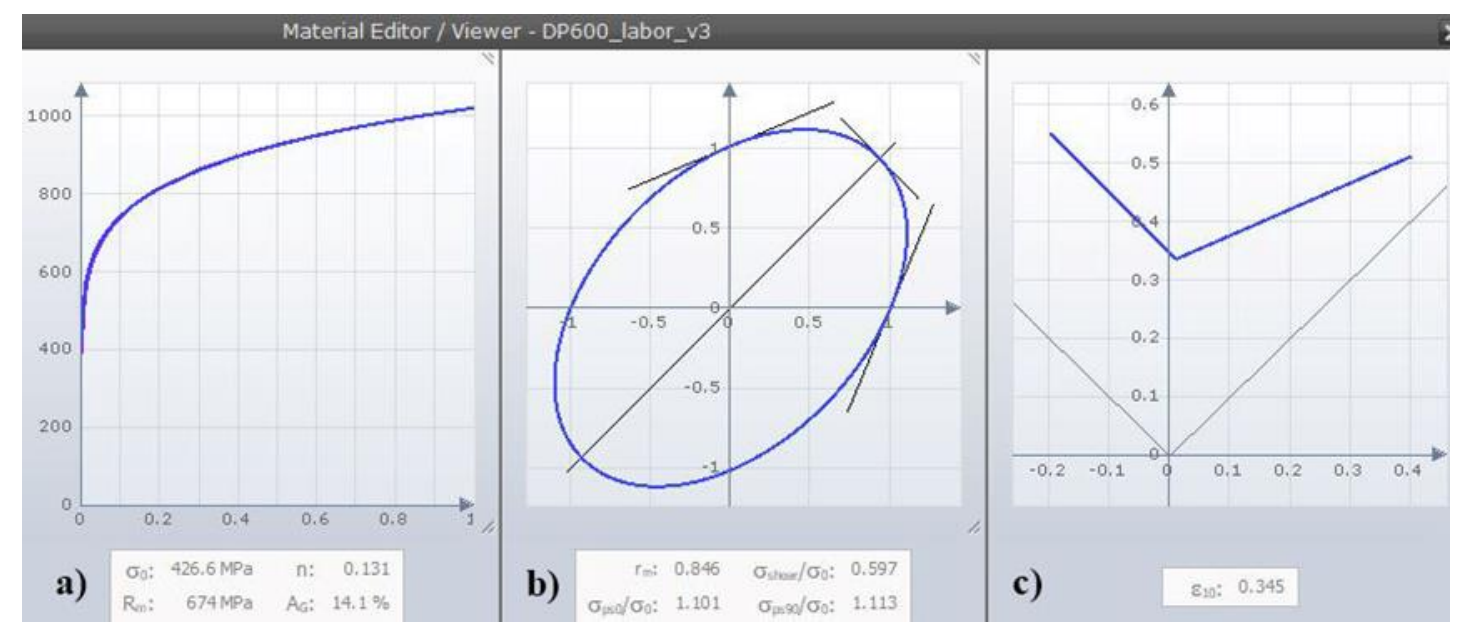

5. ábra. a) folyásgörbe, b) folyási határfelület és c) alakitási határgörbe

A szoftver utolsó szakasza az „Evaluation” fázis, ahol a szimulációból kapott eredmények kiértékelése történik. Ebben a szakaszban egy idővonalon követhető végig a próbatest alakváltozása és ezzel összhangban a megadott anyaghoz tartozó alakítási határdiagramon a próbatest minden pontja láthatóvá válik, ezáltal nyomon követhető a szakadás pillanata és helye (6. ábra).
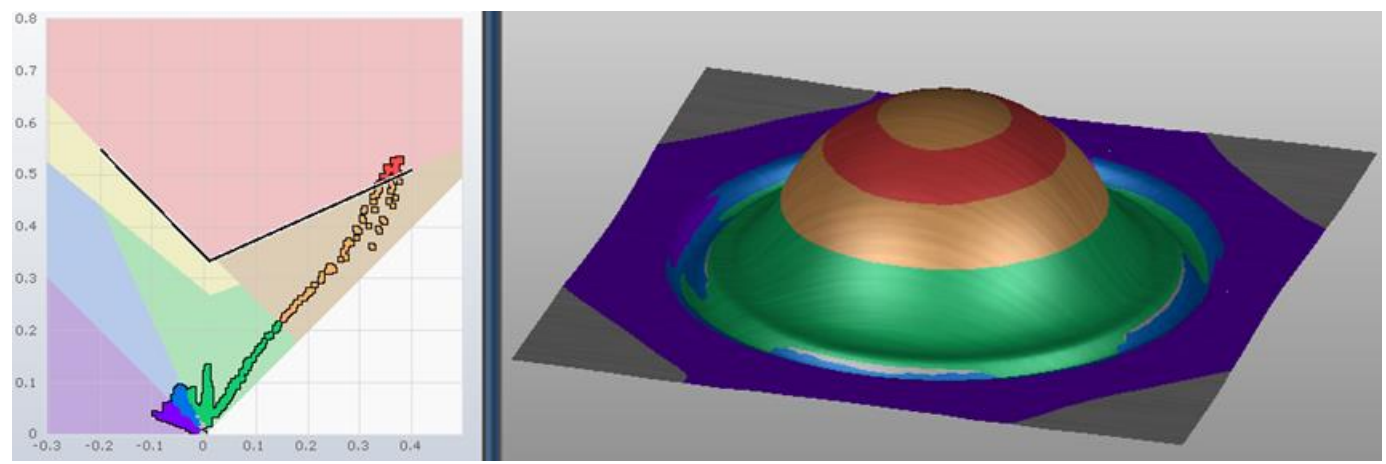

6. ábra. A szimuláció eredménye a kiértékelési fázisban 
A fenti kép jobb oldalán a próbatest az alakítás utáni állapotban, a baloldalon pedig az alakításhoz tartozó FLD látható.

Annak érdekében, hogy a teljes FLD diagramra kapjak eredményeket, ezért a kivágás nélküli próbatesten kívül a $125 \mathrm{~mm}, 80 \mathrm{~mm}, 40 \mathrm{~mm}$ és $20 \mathrm{~mm}$ hídszélességü próbatestekre is elvégeztem a szimulációt. A próbatest kialakításokat a 7 . ábra mutatja.

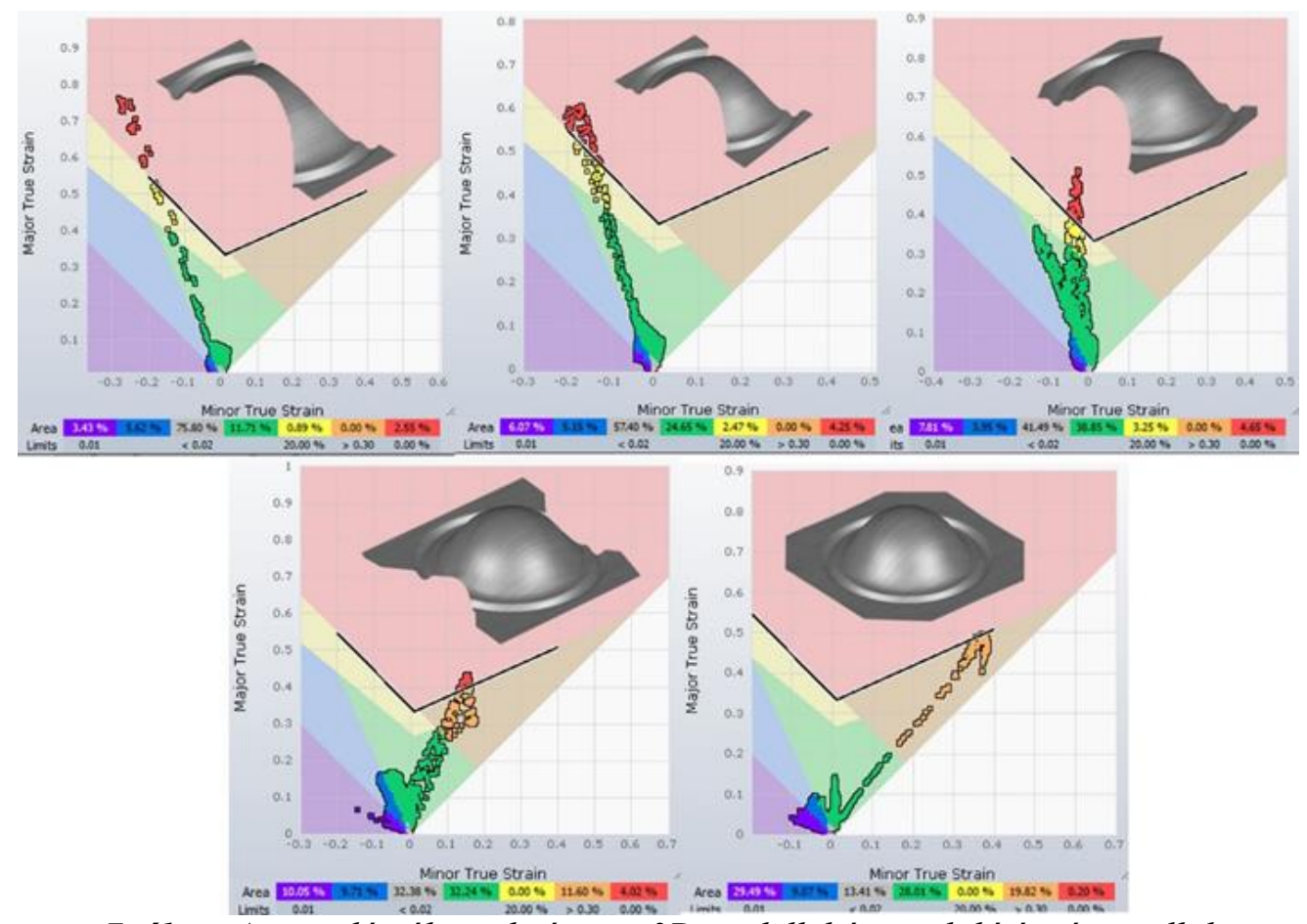

7. ábra. A szimulációk eredménye a 3D modellel és az alakitási útvonallal

A fenti képen látható geometriai módosításokat leszámítva a szoftverben a többi fázist ugyan úgy végeztem el. A 7. ábrán jól látható, hogy a hídszélesség módosításával úgy változnak az alakítási útvonalak, hogy a teljes FLD lefedhetö vele.

\section{Az alakítási határdiagramot befolyásoló paraméterek hatása}

Az elöző pontban létrehoztam a Nakazima vizsgálatot az AutoForm R7 szoftverben és úgy módosítottam azt, hogy az FLC görbe, azaz a szakadás körüli időpillanatot a lehető legpontosabban szimulálni és vizsgálni tudjam. A következőkben az a célom, hogy a vizsgálatot befolyásoló paraméterek elemzésével úgy változtassam a szimulációkat, hogy a tényleges, laboratóriumi vizsgálathoz legközelebbi állapot valósuljon meg. Az FLD diagramot és a lemez alakíthatóságát számos paraméter befolyásolja. Ezek lehetnek: anyagminőség, lemezvastagság, alakítási sebesség, hőmérséklet, próbatest geometria, súrlódás (azaz az alkalmazott kenés) és a próbatest kimunkálása a hengerlési irányhoz képest. 


\subsection{Súrlódás hatása}

A szimulációk úgy kerültek elvégzésre, hogy a súrlódási együttható $(\mu)$ értékét alapbeállításon hagytam, ami a szoftverben elöre meghatározott $\mu=0,15$ értéken volt. A súrlódási együttható értékének befolyásoló hatását a 20,80 és $200 \mathrm{~mm}$ hídszélességü próbatest esetében vizsgáltam meg, mert ezzel a három próbatesttel az FLD diagramot teljes kiterjedésében le lehet írni.

A szimulációk lefuttatását követő kiértékelésnél az FLD diagramon látható pontfelhőkből látható az adott próbatest alakítási útvonala. A $200 \mathrm{~mm}$ hídszélességủ próbatestből kiindulva megvizsgáltam, hogy ha a súrlódási együttható eredeti értéket megnövelem vagy lecsökkentem, akkor az milyen hatással lesz az alakítási útvonalra, azaz az adott FLD-re. A $\mu$ értékének változtatását követően a kiértékelésnél látható FLD diagramokat és alakítási útvonalak a 8. ábrán hasonlítottam össze.

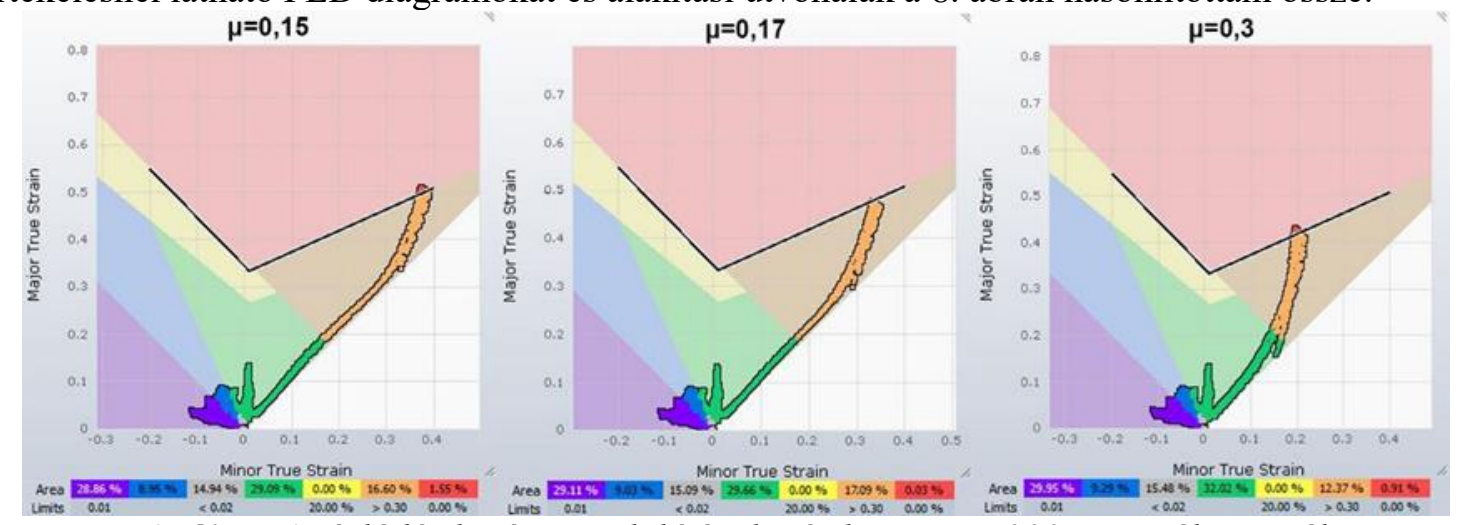

8. ábra. A súrlódás hatása az alakitási határdiagramra $200 \mathrm{~mm}$ próbatestnél

A fenti képen balról jobbra haladva a súrlódási együtthatók értéke a következő: $\mu=0,15, \mu=0,17$ és $\mu=0,3$. A képek alapján látható, hogy a súrlódás növelésével az alakváltozási útvonal $\varepsilon 2$ tengelyen a 0 érték felé (balra) tolódik. Fontos megjegyezni, hogy az FLC-t nem befolyásolja a súrlódás hatása, tehát a görbében nem következik be eltolás. A $\mu$ hatása az alakváltozási útvonal meghatározásán kívül a repedés keletkezés helyére is kihatással van. Továbbra is a $200 \mathrm{~mm}$ próbatestet tekintve, ha a lehetö legjobb kenést feltételezzük, azaz a súrlódási tényező értékét nullára $(\mu=0)$ csökkentjük, akkor a repedés a próbatest közepén, azaz a bélyeg csúcsánál fog megjelenni. Ellenben, ha a súrlódási tényező érték növeljük, akkor a repedéskeletkezés tartománya a bélyeg csúcsától lefelé haladva egy körgyürü mentén jelenhet meg.

Az FLC görbe meredekségéböl adódóan és az alakítási útvonalak különbsége miatt, a súrlódási tényező hatással van a lemez alakíthatóságára is. Nagyobb súrlódás balra tolja a pontfelhőt, amely pontban az FLC görbe alacsonyabban helyezkedik el, így kisebb alakváltozást visel el az anyag. Minél kisebb súrlódás esetén a pontfelhő az FLC magasabban lévő tartományait érinti, így a repedés egy későbbi időpillanatban következik be, tehát nagyobb alakváltozás után. A fenti képen ez a hatás is jól látható, hiszen a baloldali ábrán a próbatest magasabb, tehát nagyobb alakítást viselt el.

A vizsgálatnál grafitos kenőanyagot alkalmaztam, viszont a tényleges súrlódási viszonyokat a laborban nem tudom meghatározni. A szoftverben a 20, 80 és 200 mm hídszélességü próbatesteknél megkerestem azt a súrlódási tényező értéket, mellyel a vizsgálatnál felvett FLD alakítási útvonalát a 
lehető legjobb közelítéssel visszakaptam. A 9. ábrán összehasonlítottam a laboratóriumi vizsgálatokból származó FLD-k alakítási útvonalait az AutoForm szoftverben létrehozottéval.

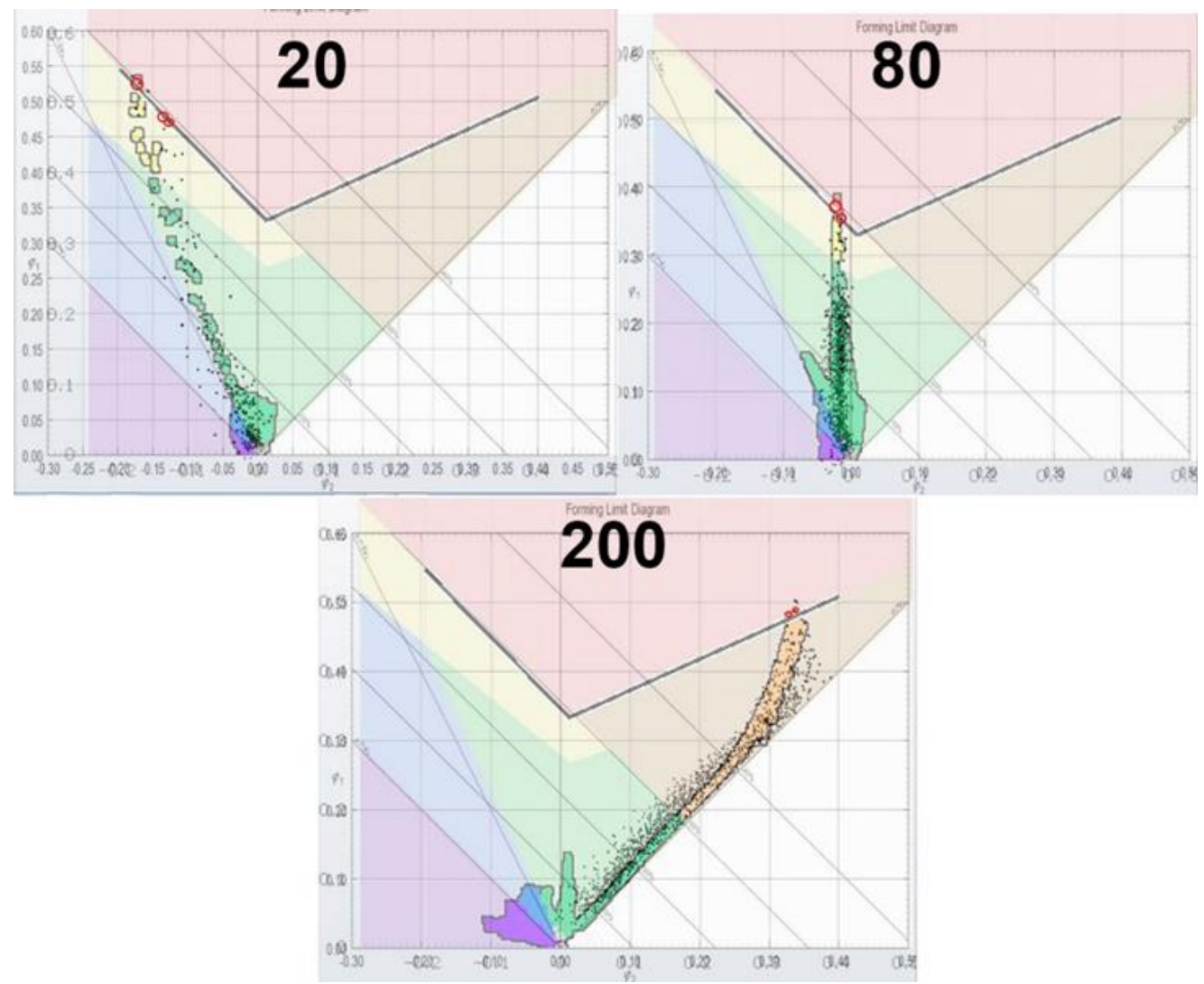

9. ábra. A laboratóriumi és az AutoForm -os FLD diagramok összehasonlitása

Az előző ábrán sorra láthatók a 20,80 és 200 mm hídszélességü próbatestek laboratóriumban felvett és az AutoForm szoftveres szimulációban létrehozott FLD diagramjaik egy közös diagramon ábrázolva. A felső fekete pontfelhő szemlélteti a vizsgálattal felvett FLD-ben az alakítási útvonalat, míg a színes (zöld-sárga-piros) pontokból álló alakítási útvonal az AutoForm szimulációkból származik. A $200 \mathrm{~mm}$ próbatest esetében $\mu=0,17$ volt az a súrlódási együttható érték, mellyel a pontfelhő ugyan ott éri el az FLC görbét, mint a vizsgálat során. A $80 \mathrm{~mm}$ hídszélességü próbatestnél a súrlódási együtthatót $\mu=0,11$ értékre kellet csökkenteni, hogy a szimulációban azonos eredményt érjek el a vizsgálathoz képest. A $20 \mathrm{~mm}$ próbatest esetében egészen $\mu=0,01$ értékre csökkentettem a súrlódást, de még így sem sikerült visszakapnom pontosan ugyan azt a pontot ahol a vizsgálat során elszakadt a próbatest. Ennél a hídszélességnél a súrlódás csökkentése vagy növelése minimális befolyással volt az alakítási útvonalra. Mivel a hídszélesség ennél a próbatestnél meglehetősen keskeny a súrlódástól függetlenül a repedés nagy valószínűséggel mindig a próbatest közepénél fog megjelenni. 
A felsorolt módosítások következtében a szimulációk és a tényleges vizsgálatok közötti eltérések minimalizálva lettek és egy jó közelítéssel kijelenthető, hogy sikerült a vizsgálatot és annak körülményeit szoftveres szimulációval megvalósítani. A szoftveres szimuláció egy sarkalatos ponton merőben eltér a tényleges, laboratóriumi vizsgálathoz képest. Az AutoForm rendszerben a súrlódási együttható a teljes alakítási folyamat során a próbatest és a szerszám közötti teljes felületen állandó értékű. Ez egy ideális eset, amely a gyakorlatban nem valósul meg. Ezen tulajdonság miatt, a szoftverben történő vizsgálat létrehozását követően nem lehetséges teljes mértékben „lemásolni” a laboratóriumi vizsgálat menetét, de jó közelítéssel leírható az.

\section{Következtetések}

Az említett szoftverek - mint az általam használt AutoForm R7 rendszer - is rendelkeznek anyag adatbázissal. Az ebben szereplő anyagmodellek laboratóriumi vizsgálatokkal lettek felvéve és meghatározva. A listából könnyedén kiválaszthatók és alkalmazhatók különféle alakítási müveletek esetében. Az így kapott végeredmény jó pontossággal közelíti a tényleges lemezalakítás sikerességét. Hátrányuk, hogy a felvett anyagmodellek meghatározott összetételű és gyártójú, adott lemezvastagságra végzett vizsgálatokból származó eredményeket tartalmaznak. Ennek következtében, eltérő összetételü anyagminőség és más lemezvastagság esetén a bemeneti értékek a szoftveren belül történnek átszámításra. Az így kapott végeredmény tovább csökkentett pontossággal írja le a tényleges folyamatot.

Erre a problémára nyújt megoldást, ha az alkatrész anyagának választott adott összetételü anyagminőségre a pontos lemezvastagság figyelembevételével végzünk laboratóriumi vizsgálatokat, melyekkel a szabványos anyagjellemzők és az anyag alakítási határdiagramja felvehető. Ezt követően egy végeselemes szoftverbe ezek a paraméterek bevihetők és létrehozható egy pontos anyagmodell. Ezt felhasználva a lehető legpontosabb képet kaphatjuk az alakítás sikerességét illetően az adott alkatrész esetében.

\section{Irodalom}

[1] Tisza M., Kovács P. Z.: Új próbatestkialakítás alakítási határgörbe (FLC) meghatározásához, GÉP 2012, 63:65-68.

[2] Sreenath D K., Jeyasingh, J. J.V., Amjith T.R.: Development of Nakazima Test Simulation Tool for Forming Limit Diagram Generation of Aluminium Alloys, IJESTA 2015, 10(1):37-45.

[3] Kovács P. Z.: Alakítási határdiagramok elméleti és kísérleti elemzése, Phd értekezés, Miskolc, 2012

[4] Béres G., Hareancz F., Weltsch Z.: Korszerü lemezanyagok mechanikai vizsgálata, Gradus 2016, 3(2):101-107.

[5] AutoForm Announces new product line, press release, AutoForm Engineering GmbH, 2009, p. $1-2$. 